\title{
Compared impact of compost and digestate on priming effect and hydrophobicity of soils depending on textural composition
}

\section{VergleichendeWirkung von Kompost und Gärresten auf den Priming-Effekt und die Hydrophobie von Böden in Abhängigkeit ihrer Textur}

\author{
Amrei Voelkner ${ }^{1 *}$, Charlotte Diercks ${ }^{1}$, Rainer Horn ${ }^{1}$ \\ ${ }^{1}$ Institute of Plant Nutrition and Soil Science, Christian-Albrechts-Universität of Kiel, Hermann-Rodewald-Straße 2, 24118 Kiel, Germany \\ * Corresponding author: a.voelkner@unity-mail.de
}

Received: 10 October 2018, received in revised form: 7 February 2019, accepted: 7 February 2019

\begin{abstract}
Summary
Digestates and compost are used as valuable fertilizers in agriculture because of their benefits for plant nutrition and carbon sequestration potential. These amendments are also suspected to interfere negatively with the soil. To compare their relevance for priming effect and hydrophobicity of soils, two amounts of digestate or compost, respectively, were mixed with a homogenized cambic Luvisol and a Podzol. The basal respiration rate (BAS), the repellency index (RI) and organic carbon content (Corg) of pre-dried mixtures were investigated. The podsolic mixture showed quantitative reduction of Corg and increased BAS (this effect was not statistically significant) due to priming effect through microbial stimulation. As a result of enhanced organic substance (OS) protection in the cambic Luvisol mixture, constant amounts of Corg and declined BAS could be detected. The wettability was reduced in both soils: either directly by the supply of amphiphilic components or indirectly by increased incorporation of microbial exudates. This reduction was not statistically significant. Higher contents of available organic compounds in digestates and higher amounts of hydrophobic humic acids in the compost could be assumed to be decisive for generation of hydrophobicity. Also the soil texture controlled the microbial decomposition by higher incorporation of OS in finer pores and contributed to the protection against microbial decay.
\end{abstract}

Keywords: Organic amendments, microbial activity, organic carbon, basal respiration rate, repellency index

\section{Zusammenfassung}

Gärreste sowie kompostierte organische Substanzen (OS) sind in der Landwirtschaft aufgrund ihrer Vorzüge für Pflanzenernährung und Kohlenstoffspeicherung als Düngemittel etabliert. In Abhängigkeit bodenbürtiger Parameter stehen diese organischen Düngemittel allerdings im Verdacht, die Bodenmatrix nachteilig zu beeinflussen. Um die Bedeutung von Gärrückständen und Kompost für den Priming-Effekt und die Hydrophobie von Böden zu vergleichen, wurden zwei Mengen Gärrest bzw. Kompost mit einem homogenisierten Cambic Luvisol (Ut3) und einem Podsol (Ss) in einem Laborexperiment kombiniert. Hierzu wurden die basale Respirationsrate (BAS), der Repellency Index (RI) sowie der organische Kohlenstoffgehalt (Corg) bestimmt. Nach der OS-Applikation zeigten sich im Ss eine quantitative Reduktion von Corg und eine erhöhte BAS aufgrund des Priming-Effekts. Als Folge des erhöhten Schutzes der OS vor mikrobiellem Abbau im Ut3 konnten konstante Mengen von Corg und eine sinkende BAS nachgewiesen werden. Die Benetzbarkeit war in beiden Böden verringert; im Ut3 direkt durch die Zufuhr amphiphiler Komponenten und indirekt im Ss durch Präsenz von mikrobiellen Exsudaten. Höhere Gehalte an leicht verfügbaren organischen Verbindungen in Gärresten und größere Mengen an hydrophoben Huminsäuren im Kompost können als entscheidende Faktoren für die reduzierte Benetzbarkeit angesehen werden. Zusätzlich werden die mikrobielle Aktivität und folglich Zersetzungs- und Freisetzungsvorgänge maßgeblich durch die Zusammensetzung der Textur determiniert.

Schlagworte: Organische Düngemittel, mikrobielle Aktivität, organischer Kohlenstoff, Basale Respirationsrate, Repellency Index 


\section{Introduction}

The on-going worldwide discussion on realization and satisfaction of environmental targets requires a strategy for sustainable use of resources (Holm-Nielsen et al., 2009) that are economically viable and environmentally sound (Alburquerque et al., 2012a). Because of an increased awareness on carbon dioxide release and related climate change, vast amounts of biodegradable organic wastes (e.g. slurries, green wastes and agricultural residues) (Mshandete et al., 2006), present in most countries, are suitable to generate renewable or thermal energy (e.g. as biogas). The microbial decomposition of these organic residues generates by-products, which are used as high-valued fertilizers in agriculture: compost under aerobic conditions or digestate as a result of oxygen deficiency (Tambone et al., 2010; García-Bernet et al., 2011; Odlare et al., 2011; Bustamante et al., 2012). Compost and digestates differ - as a result of their generation process - in their composition and could potentially pose major risks for atmosphere, groundwater and the functionality of soils when spreading on arable land. Interactions between soil matrix and the humic substances of these amendments, combined with various amounts of fatty acids especially contained in anaerobically produced substances, can modify soil wettability (Bayer and Schaumann, 2007). As a result of the amphiphilic character of such molecules, hydrophobic conditions can be intensified when soil water content falls below a critical level (Woche et al., 2005). It is frequently reported that compost and digestate augment the microbial activity in soils by the incorporation of organic substance (OS) into new microbial biomass (Tejada et al., 2006; Hurisso et al., 2013). Odlare et al. (2008) found the activity of microorganisms to increase after digestate application compared to compost supply. The subsequent higher production of microbial exudates may cause enhanced cohesion between soil particles and, hence, soil stability (Chenu et al., 2000; Mataix-Solera and Doerr, 2004; Mylavarapu and Zinati, 2009), but may also contribute to soil hydrophobicity (Hallett and Young, 1999). Because the composition of organic residues differs among compost and digestates, the organic carbon $\left(\mathrm{C}_{\text {org }}\right)$ fraction was detected to either increase (Ros et al., 2006; Fabrizio et al., 2009) or remain unchanged (Quédraogo et al., 2001; Abdel-Rahman, 2009) after compost application. During digestion, a major part of easily degradable $\mathrm{C}_{\text {org }}$ is transferred into methane and carbon dioxide $\left(\mathrm{CO}_{2}\right)$ and will not serve as a carbon source for soil C-stock. Accordingly, the organic residues available in the digestates become stabilized in a fermenter, but not that much compared to OS present in compost (Odlare et al., 2008).
For their economical as well as ecological value as fertilizer, compost and digestates have to fulfil innocuousness for buffer-, conservation- and transport-capacity of soils. However, the compared effects of compost and digestates on chemical and microbiological soil properties as a function of soil texture remain still incomplete. This information would be essential to understand the interaction with various soil types across the borders and ensure a sustainable way of using those OS (Rowell et al., 2001). We hypothesized that the application of both amendments implies hydrophobic conditions and promotes microbial activity, inducing a priming effect. We further assumed a higher sensitivity of the loamy compared to the sandy soil as a result of an inherent higher specific surface area of clay particles.

Therefore, the major aims of this laboratory study were

1. to determine the effects of differently treated organic wastes (aerobic vs. anaerobic) on hydrophobicity in a loamy and sandy soil,

2. to investigate the change of $\mathrm{C}_{\text {org }}$ content as well as microbiological activity with regard to the applied amendment in order to

3. draw a close connection between the detected parameters.

\section{Material and methods}

\subsection{Experimental sites and soil characteristics}

For the laboratory investigations of chemical $\left[\mathrm{C}_{\mathrm{org}}\right.$ and repellency index (RI)] and biological [basal respiration rate (BAS)] parameters, homogenized soil from two arable land sites differing in texture were sampled from the topsoil (A-horizon, 0 to $10 \mathrm{~cm}$ ) in June 2014 under warm and dry conditions: an Ae-horizon of a sandy Podzol derived from glacial outwash from the research farm Karkendamm of the University of Kiel, near Kiel, and a topsoil horizon of a loamy cambic Luvisol derived from weichselian glacial till from the research farm Dikopshof of the University of Bonn, near Wesseling. According to the German texture classification (AG Boden, 2005), the soil from Karkendamm was characterized as a sandy sand (Ss), whereas the soil from Dikopshof was classified as a strong clayey silt (Ut3) (Table 1). The topsoil of the sandy sand from Karkendamm was slightly acid and exhibited twofold more $\mathrm{C}_{\text {org }}$ compared to the strong clayey silt from Dikopshof. The Ss showed two times higher carbon content compared to the Ut3, as the carbon-rich subsoil horizon was ploughed into the topsoil in the 1980s as a result of deep mixing measures to 
Table 1. Soil Characteristics of the Investigated Arable Sites [Karkendamm (Ss) and Dikopshof (Ut3)]

Tabelle1. Bodeneigenschaften der untersuchten Böden Ss (Karkendamm) und Ut3 (Dikopshof)

\begin{tabular}{lll}
\hline & \multicolumn{2}{l}{ Soil Textures } \\
\cline { 2 - 3 } & Ss & Ut3 \\
\hline $\mathrm{pH}\left(0.02 \mathrm{~m} \mathrm{CaCl}_{2}\right)(-)$ & 5.3 & 7.1 \\
Electrical conductivity $\left(\mu \mathrm{S} \mathrm{cm}^{-1}\right)$ & 86 & 182 \\
Organic carbon $\left(\mathrm{C}_{\text {org }}\right)(\%)$ & 2.8 & 0.3 \\
Texture & & \\
Clay (\%) & 2.6 & 14.9 \\
Silt (\%) & 5.8 & 77.9 \\
Sand $(\%)$ & 91.5 & 7.2 \\
\hline
\end{tabular}

improve water holding capacity and rootability, which finally should also improve the air conductivity.

The A-horizon of the Ut3 possessed alkaline conditions and showed more than twice the level of the electrical conductivity compared to the Ss.

\subsection{Properties of compost and digestate}

Converted compost, derived from garden and park wastes, was produced at the composting plant in Bülk, SchleswigHolstein. According to the RAL Quality Assurance (2014), the applied compost was classified as NPK-fertilizer with a certain amount of trace nutrients. With a rotting degree of five, the used compost exhibits a high degree of ripeness.

The liquid digestates were generated in batch fermentation under laboratory conditions at the Institute of Agricultural Engineering at the University of Kiel. A total of 20 to $30 \mathrm{~g}$ of fresh input substrate from $80 \%$ maize and $20 \%$ sugar beet silage (ground and dried at $58^{\circ} \mathrm{C}$ ) was added to a microbial inoculum, derived from the biogas plant in Bülk, SchleswigHolstein, before starting the digestion process. The mixture was digested at a defined temperature of $38^{\circ} \mathrm{C}$ for 28 days in nine repetitions. A composite sample of the nine repetitions was applied to soils.

The chemical analysis of the compost was based on the description of the test certificate of the RAL Quality Assurance.
The chemical investigations of the digestate were conducted at the LUFA GmbH, Kiel. The $\mathrm{pH}$ and the base saturation ( $S$-value) were analysed following standard procedures (Schlichting et al., 1995).

Both amendments, compost as well as digestate, were characterized by alkaline conditions (Table 2). The compost exhibited about 20-fold higher level of dry substance compared to digestate. The digestate showed higher cation exchange capacity ( $S$-value) and greater amounts of cations than the composted OS.

\subsection{Sample preparation}

To compare the impact of compost and digestate on chemical soil parameters, air-dried and homogenized (sieved to $<2 \mathrm{~mm}$ ) soil was mechanically mixed with two amounts of compost and digestate. The applied amounts of the amendments were equivalent to the usual annual compost application rate per hectare of $10 \mathrm{tDS} \mathrm{ha}^{-1}$, respectively $30 \mathrm{tDS} \mathrm{ha}^{-1}$ for 3 years, and 30 to $40 \mathrm{~m}^{3} \mathrm{ha}^{-1}$ for digestate (Wendland and Fischer, 2013). All mixtures had the same water content. The smaller water content of the soil-compost-mixture (SCM) was compensated by the addition of demineralized water, so that all mixtures ended up with similar soil water content. Additionally, the calculation referred to $15 \mathrm{~cm}$ soil depth to take into account the supply of the fertilizer into the topsoil. Comparable to the high compost rate, the digestate was also incorporated into the soil in the threefold amount. Besides, a reference $(\mathrm{R})$ was established using an equivalent amount of demineralized water instead. During the exposure time of 1 day for the SCM, the soil-digestate-mixtures (SDM) and the untreated reference, the mixtures were stored at $10^{\circ} \mathrm{C}$. Afterwards, one part of the amendments was again air-dried and sieved to $\leq 2 \mathrm{~mm}$. From SCM, SDM and R, four repetitions were finely ground in the ball mill for the analysis of $\mathrm{C}_{\text {org }}$. To determine the sorptivity of water and ethanol into the soil, the remaining part of the mixtures was compacted to a bulk density of $1.45 \mathrm{~g} \mathrm{~cm}^{-1}$ for Ss or $1.4 \mathrm{~g} \mathrm{~cm}^{-1}$ for Ut3 in 6 cylinders $\left(100 \mathrm{~cm}^{3}\right)$ for each amendment and soil texture. For investigations of BAS, cylinders of $19.5 \mathrm{~cm}^{3}$ were prepared with

Table 2. Properties of Compost and Digestate

Tabelle 2. Eigenschaften des Komposts und des Gärrests. OS = Originalsubstanz, DS = Trockensubstanz

\begin{tabular}{|c|c|c|c|c|c|c|c|c|c|}
\hline & $\mathrm{pH}$ & $\begin{array}{c}\text { DS } \\
\% \text { OS }\end{array}$ & $\begin{array}{c}S \text {-value } \\
\mathrm{cmol}_{\mathrm{c}} \mathrm{kg}^{-1}\end{array}$ & $\mathrm{~N}_{\mathrm{t}}$ & $\mathrm{NH}_{4}-\mathrm{N}$ & $\mathrm{P}$ & K & $\mathrm{Mg}$ & $\mathrm{Ca}$ \\
\hline Compost & 8.2 & 56 & 22.1 & 1.3 & N.A. & 0.2 & 0.7 & 0.2 & 2.4 \\
\hline Digestate & 7.7 & 2.7 & 94.7 & 6.7 & 5.2 & 11 & 1.6 & 1.4 & 8.5 \\
\hline
\end{tabular}


a bulk density of $1.45 \mathrm{~g} \mathrm{~cm}^{-3}$, respectively $1.4 \mathrm{~g} \mathrm{~cm}^{-3}$ in three replicates. Afterwards, the cylinders were pre-dried to $-60 \mathrm{hPa}$ for 7 days or 10 days, respectively, to achieve an equilibrated matric potential. The amendments and their abbreviations are summed up in Table 3.

\subsection{Soil measurements}

\subsubsection{Organic carbon $\left(\mathrm{C}_{\text {org }}\right)$ and repellency index $(\mathrm{RI})$}

The organic carbon $\left(\mathrm{C}_{\text {orr }}\right)$ content of air-dried, finely milled samples from SCM, SDM and R was determined coulometrically in fourfold replications following standard procedures (Blume et al., 2011).

Wetting properties of the moist (pre-dried to $-60 \mathrm{hPa}$ ) samples were evaluated in sixfold replication by detecting the RI using a microinfiltrometer developed by Tillman et al. (1989). The RI is defined as the ratio between the intrinsic sorptivity $(S)$ of water (non-wetting) and ethanol (wetting) as reference liquid. The sorptivity can be calculated from the time-dependent infiltration rate of soil every 15 seconds $(Q)$, the air-filled porosity $(f)$, the infiltrometer tip radius $(r=1.4$ $\mathrm{mm})$ and the parameter $b(0.55)$, which depends on the soilwater diffusivity function:

$$
S=\sqrt{Q f / 4 b r}
$$

The infiltration capacity of soils can be expressed with the RI from the relationship of the intrinsic sorptivity of water $\left(S_{\text {water }}\right)$ and ethanol $\left(S_{\text {ethanol }}\right)$ by the formula

$$
\mathrm{RI}=1.95\left(S_{\text {ethanol }} / S_{\text {water }}\right)
$$

where the constant 1.95 represents the differing surface tension and velocity of water and ethanol. Whereas an $\mathrm{RI}=1$ shows hydrophilic conditions, an $\mathrm{RI} \geq 1.95$ represents hydrophobicity. Detailed description of the method is given by Hallett and Young (1999).

\subsubsection{Basal respiration rate (BAS)}

The impact of compost and digestates on microbial activity was evaluated by measuring the release of $\mathrm{CO}_{2}(\mu \mathrm{g} \mathrm{CO}$ $\mathrm{g}^{-1} \mathrm{~h}^{-1}$ ) by titration according to Pell et al. (2006) with three replicates for each amendment and texture. The determined $\mathrm{CO}_{2}$ release was normalized to the influence of atmospheric $\mathrm{CO}_{2}$ using three blank value measurements. For analysis of BAS, moist SCM, SDM and R (pre-dried at $-60 \mathrm{hPa}$ ) were pre-incubated at $22^{\circ} \mathrm{C}$ to wait for the initial flush of $\mathrm{CO}_{2}$.
Table 3. Description and Declaration of the Amendments regarding the Topsoil of $15 \mathrm{~cm}$ Depth

Tabelle 3. Beschreibung und Bezeichnung der Varianten bezogen auf eine Bodentiefe von $15 \mathrm{~cm}$. DS = Trockensubstanz, OS = Originalsubstanz

\begin{tabular}{cc}
\hline Amendment & Declaration \\
\hline Reference (demineralized water) & $\mathrm{R}$ \\
$10 \mathrm{t}$ DS compost $+1500 \mathrm{~m}^{-3}$ soil & $\mathrm{C} 10$ \\
$30 \mathrm{t}$ DS compost $+1500 \mathrm{~m}^{-3}$ soil & $\mathrm{C} 30$ \\
$40 \mathrm{~m}^{3}$ OS digestate $+1500 \mathrm{~m}^{-3}$ soil & $\mathrm{D} 40$ \\
$120 \mathrm{~m}^{3}$ OS digestate $+1500 \mathrm{~m}^{-3}$ soil & D120 \\
\hline
\end{tabular}

DS, dry substance; OS, original substance.

After 6 days, incubation vessels were filled with $\mathrm{CO}_{2}$-free air. Afterwards, the amended samples were placed at the ground and a cup of $2 \mathrm{ml}$ of $0.1 \mathrm{M}$ sodium hydroxide on a perforated plate above the sample. A scheme of the experimental design is shown in Figure 1.

During an incubation time of $6 \mathrm{~h}$ at a temperature of $22^{\circ} \mathrm{C}$, the microbial released $\mathrm{CO}_{2}$ molecules were captured and stored in sodium hydroxide as a result of the following chemical reaction:

$$
\mathrm{CO}_{2}+2 \mathrm{NaOH} \leftrightarrow \mathrm{Na}_{2} \mathrm{CO}_{3}+\mathrm{H}_{2} \mathrm{O}
$$

The amount of hydroxide ions contained in sodium hydroxide was back-titrated with $0.05 \mathrm{M}$ hydrochloric acid. The amount of remaining hydroxide ions enables a direct prediction of the content of released $\mathrm{CO}_{2}$ and serves as an indirect indicator for microbial activity. The BAS was calculated from the molecular mass $M_{\mathrm{c}}$ of $\mathrm{CO}_{2}\left(12.01 \mathrm{~g} \mathrm{~mol}^{-1}\right)$, the volume of used hydrochloric acid during the back-titration for the blank test sample $V_{\mathrm{b}}(\mathrm{ml})$ and the mixtures $V_{\mathrm{s}}(\mathrm{ml})$, the dry substance of the sample $S_{\mathrm{dw}}(\mathrm{g})$ as well as the incubation time $t(\mathrm{~h})$.

$$
\operatorname{BAS}\left(\frac{\mu \mathrm{g} \mathrm{CO}_{2}-\mathrm{c}}{\mathrm{g} \mathrm{TM} \mathrm{h}^{-1}}\right)=\frac{M_{\mathrm{c}}\left(V_{\mathrm{b}}-V_{\mathrm{S}}\right) 0.01}{S_{\mathrm{dw}} \cdot t \cdot 2} \times 10^{3}
$$

Because of the different valence, two hydroxide ions react with one molecule of $\mathrm{CO}_{2}$, which is described in the denominator by the factor 2 .

\subsection{Statistical analysis}

For validation of data, the statistic software $\mathrm{R}$ (version 2.15.3) was used. After a graphical residue analysis (Shapiro-Wilk test), values of $\mathrm{C}_{\text {org }}$, $\mathrm{RI}$ and BAS were assumed to be normal- 


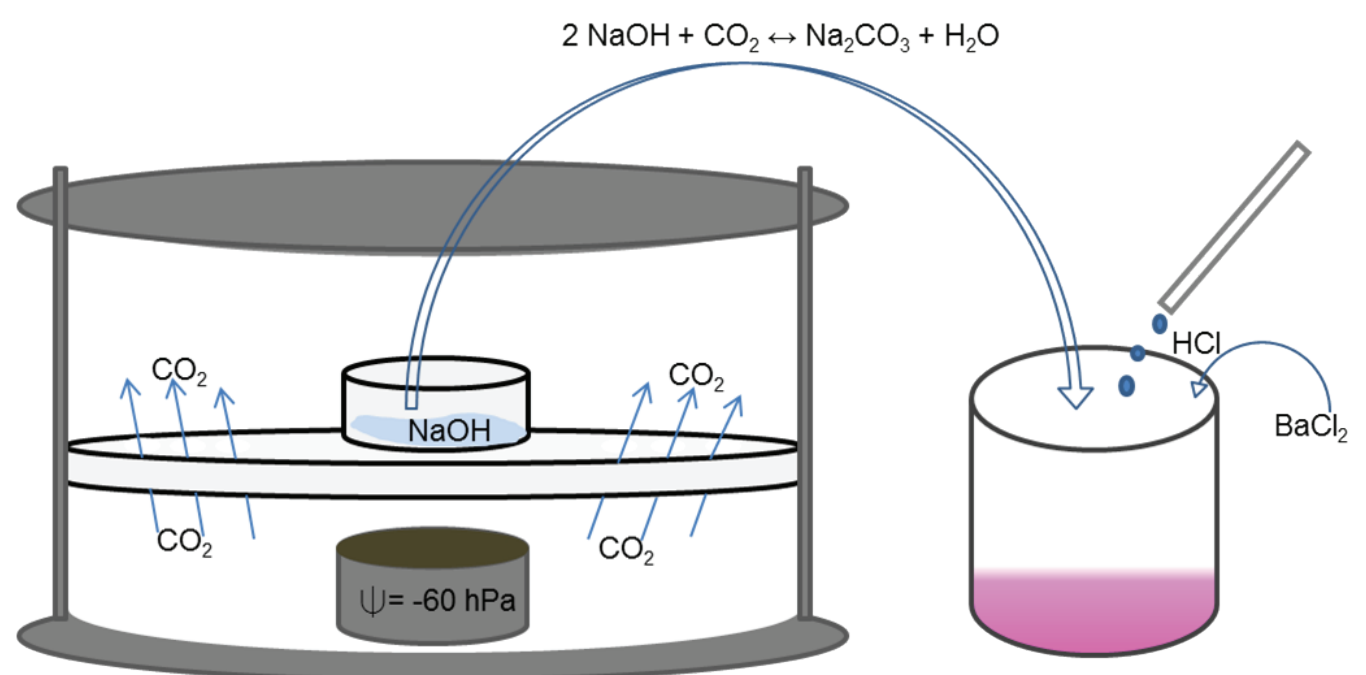

Figure 1. Schematic experimental design of the basal respiration by titration after pre-drying at $-60 \mathrm{hPa}$.

Abbildung 1. Schematische Darstellung des Versuchsaufbaus zur Messung der basalen Respiration durch Titration anhand der auf -60 hPa vorentwässerten Proben

ly distributed and heteroscedastic. The statistical model included the soil textures, the unamended reference $\mathrm{R}$ and the mixtures $(\mathrm{C} 10, \mathrm{C} 30, \mathrm{D} 40, \mathrm{D} 120)$ as well as their interaction terms. Analysis of variance (ANOVA) was applied to investigate the statistical significance among texture and amendments (Tukey test). The Dunnett test was assessed to evaluate the several levels of influence factors.

\section{Results}

\subsection{Organic carbon content $\left(\mathrm{C}_{\text {org }}\right)$ and basal respiration rate (BAS)}

The application of compost and digestate to the sandy sand $(\mathrm{Ss})$ resulted in a significant $(\mathrm{p}<0.05)$ lowering of $\mathrm{C}_{\text {org }}$ content compared to the reference (Figure 2). Stirring of digestate into the $\mathrm{Ss}$ dropped the amount of $\mathrm{C}_{\mathrm{org}}$ more in- tensively compared to compost. Further decline occurred with rising intensity of amendments (C30 and D120).

The development of the $\mathrm{C}_{\text {org }}$ content in the clayey silt (Ut3) showed the opposite trend. Merely the amendments C10 and C30 resulted in a slight increase of $\mathrm{C}_{\text {org }}$, the variant D120 exhibited an almost unchanged picture, whereas a weak decline of $\mathrm{C}_{\text {org }}$ occurred on applying digestate in moderate amount (D40) (Figure 2). Altogether, an increased application volume resulted in a slight enlargement of $\mathrm{C}_{\text {org }}$. The reference of $S$ s exhibited a lower BAS compared to $\mathrm{R}$ of Ut3 (Figure 3). After the application of compost [soil compost amendment (SCA)] and digestate [soil digestate amendment (SDA)] to Ss, the BAS increased clearly above the reference, which was significant for the amendment $\mathrm{D} 120(\mathrm{p}<0.05)$. The higher the added amount of compost and digestate (C30, D120), the more increased the BAS. In general, the BAS expanded at even higher rates after digestate application compared to compost.

Table 4. Repellency index (RI) ( $\mathrm{n}=6$ ) of the Ss and the Ut3 after application of $10 / 40 \mathrm{t}$ DS $1500 \mathrm{~m}^{-3}$ of compost (C10, C30) and 40/120 $\mathrm{m}^{3}$ OS $1500 \mathrm{~m}^{-3}$ of digestate (D40, D120).

Tabelle 4. Repellency Index (RI) ( $\mathrm{n}=6$ ) des Ss und Ut3 nach Beimengung des Kompost in einer Menge von 10/40 t DS 1500 m³ (C10, C30) bzw. 40/120 $\mathrm{m}^{3}$ OS $1500 \mathrm{~m}^{-3}$ an Gärrest (D40, D120).

\begin{tabular}{llllll}
\hline & $\mathrm{R}$ & $\mathrm{C} 10$ & $\mathrm{C} 30$ & $\mathrm{D} 40$ & $\mathrm{D} 120$ \\
Ss & & & & \\
Ut3 & $0.9 \pm 0.2$ & $1.2 \pm 0.3$ & $1.5 \pm 0.4$ & $1.2 \pm 0.4$ & $1.0 \pm 0.2$ \\
\hline
\end{tabular}




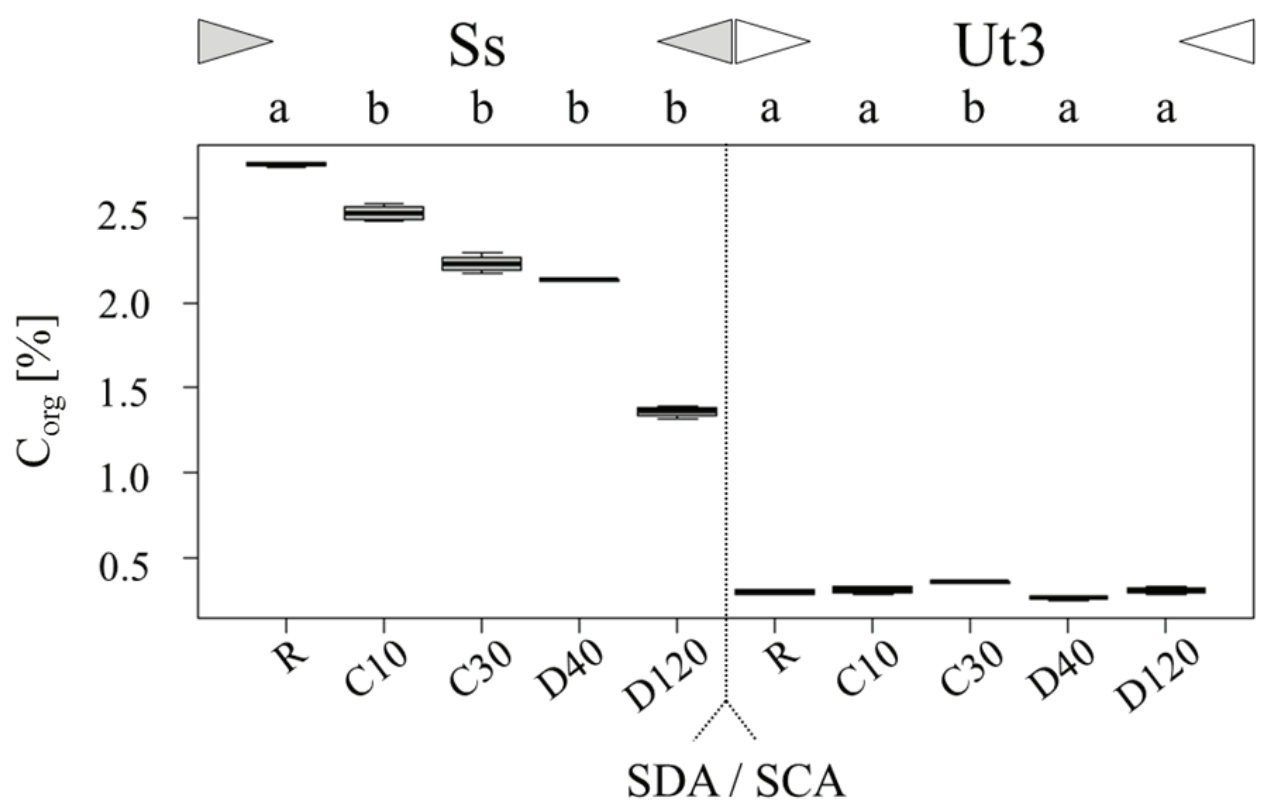

Figure 2. Organic carbon $\left(\mathrm{C}_{\mathrm{org}}\right)$ content $(\mathrm{n}=4)$ of the $\mathrm{Ss}$ and the Ut3 after application of 10/30 t DS $1500 \mathrm{~m}^{-3}$ of compost (SCA = soil compost amendment; C10, C30) and 40/120 $\mathrm{m}^{3}$ OS $1500 \mathrm{~m}^{-3}$ of digestate (SDA = soil digestate amendment; D40, D120). Different letters (a, b) indicate statistically significant differences $(\mathrm{p}<0.05)$ of the SCM and SDM in comparison to the reference $(\mathrm{R})$. Boxes represent values within the $25^{\text {th }}$ and $75^{\text {th }}$ percentile; the whiskers indicate the range, and horizontal bars inside the boxes represent the median values.

Abbildung 2. Gehalt an organischem Kohlenstoff $\left(\mathrm{C}_{\text {org }}\right)(\mathrm{n}=4)$ des Ss und des Ut3 nach Beimischung von 10/30 t DS $1500 \mathrm{~m}^{-3}$ an Kompost (C10, C30) und 40/120 $\mathrm{m}^{3}$ OS $1500 \mathrm{~m}^{-3}$ an Gärresten (D40, D120). Unterschiedliche Buchstaben (ab) zeigen statistisch signifikante Unterschiede ( $<$ <,05) von SCM und SDM im Vergleich zur Referenz (R). Die Boxen zeigen den Median und die 25/75\%-Perzentile, die Whisker die Ober- und Untergrenze der Messwerte. Die horizontalen Balken in den Boxen kennzeichnen die Mittelwerte.

An increase of BAS in Ut3 could be just noted in D120, whereas the amendments C10, C30 and D40 indicated a descent of BAS (Figure 3).

\subsection{Repellency index of pre-dried $(-60 \mathrm{hPa})$ soils}

The mixture of compost or digestate to the pre-dried $(-60 \mathrm{hPa})$ Ss and Ut3 increased the RI compared to the reference (Table 4), but higher amounts of compost resulted in lower wettability, the RI of D120 falling beyond the RI of D40.

\section{Discussion}

The impact of compost and digestate on the organic carbon content $\left(\mathrm{C}_{\text {org }}\right)$ and the BAS exhibited amendment but also texture-specific differences.

Priming occurs as a result of incorporating OS into the soil which contains easily available energy and nutrient sources. This OS stimulates the soil-inherent microbial activity, resulting in facilitated mineralization process (Kuzyakov et al., 2000). Thus, the transfer of nutrients and microorganisms with the amendments to the coarse soil matrix may trigger the beginning of priming effects in the sandy sand (Ss) whereas the higher amount of exchange places as well as an altered aeration status in the amended loamy silt Ut3 samples resulted in a nearly constant behaviour. Thus, the elevated mineralization of organic constituents as a result of stimulated microbial activity after application of compost and digestate coincides with an increased BAS and a subsequent decline of $\mathrm{C}_{\text {org }}$ in the $\mathrm{Ss}$. By virtue of the higher increase of BAS after digestate amendment compared to compost application, even stronger priming effects of D40 and D120 are expected and could also be proofed. These findings also correspond to the assumption of Kirchmann and Bernal (1997), who reported the OS of highly mature compost to be more stabilized than the OS derived from anaerobic fermentation processes. Thus we need to expect such trends, because the application of digestates offers a higher content of easily decomposable residues compared to compost. However, priming cannot be detected in the 


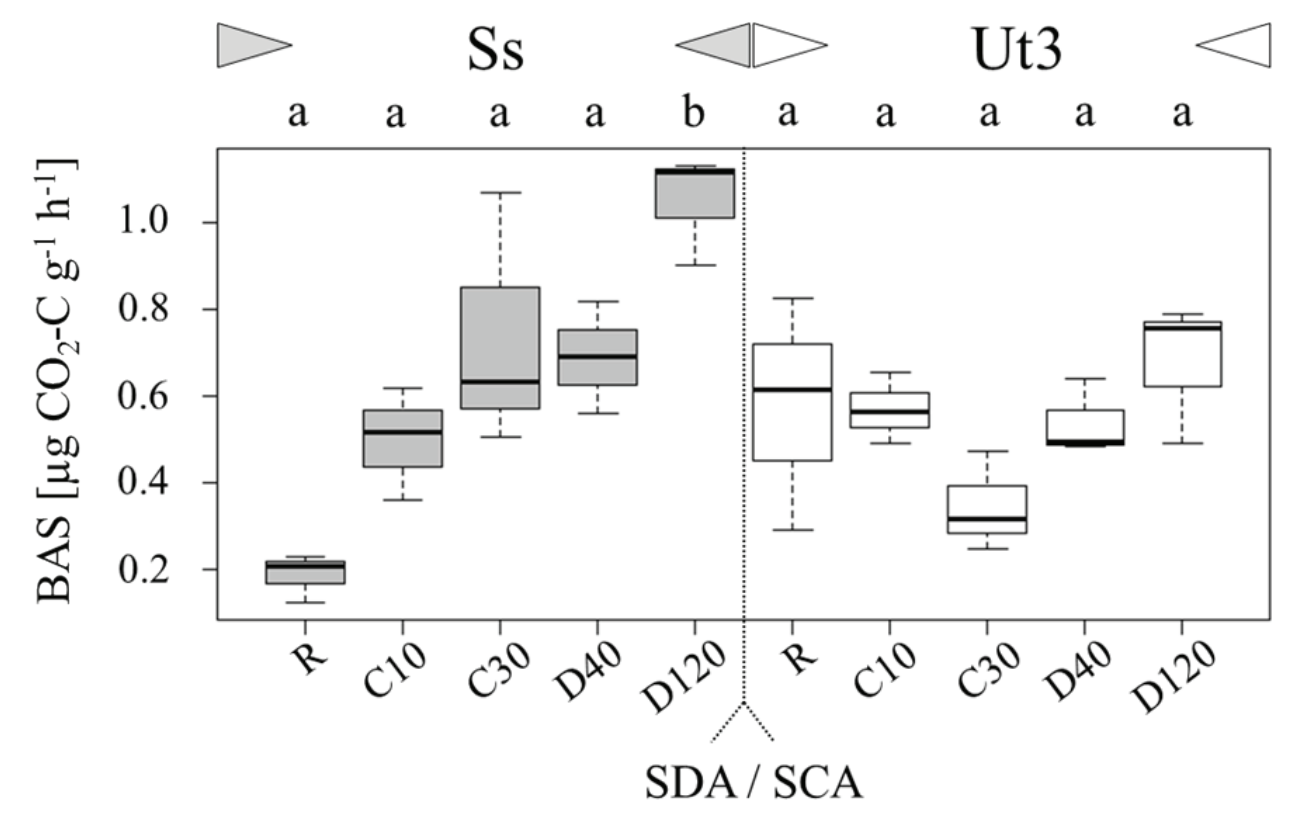

Figure 3. Basal respiration rate (BAS; $\mathrm{n}=3$ ) of the $\mathrm{Ss}$ and the Ut3 after application of 10/30 t DS $1500 \mathrm{~m}^{-3}$ of compost (SCA = soil compost amendment; C10, C30) and 40/120 $\mathrm{m}^{3}$ OS $1500 \mathrm{~m}^{-3}$ of digestate (SDA = soil digestate amendment; D40, D120). Different letters (a, b) indicate statistically significant differences $(\mathrm{p}<0.05)$ of the SCM and SDM in comparison to the reference $(\mathrm{R})$. Boxes represent values within the 25 th and 75 th percentile; the whiskers indicate the range, and horizontal bars inside the boxes represent the median values.

Abbildung 3. Basale Respirationsrate (BAS; $n=3)$ des Ss und des Ut3 nach Beimischung von 10/30 t DS $1500 \mathrm{~m}^{-3}$ an Kompost (C10, C30) und $40 / 120 \mathrm{~m}^{3}$ OS $1500 \mathrm{~m}^{-3}$ an Gärresten (D40, D120). Unterschiedliche Buchstaben (ab) zeigen statistisch signifikante Unterschiede ( $\left.\mathrm{p}<0,05\right)$ von SCM und SDM im Vergleich zur Referenz (R). Die Boxen zeigen den Median und die 25/75\%-Perzentile, die Whisker die Ober- und Untergrenze der Messwerte. Die horizontalen Balken in den Boxen kennzeichnen die Mittelwerte.

Ut3 - with the exception of D40. The steady, respectively increasing level of $\mathrm{C}_{\text {org }}$ after addition of compost and digestate in $\mathrm{Ut} 3$ is in line with the findings of Fabrizio et al. (2009), who described rising $\mathrm{C}_{\text {org }}$ contents in a silty loam, which is more pronounced with rising fertilization intensity. Eventhough the texture-specific effect is dominant, the amendment-specific differences [higher quantities of stabilized organic compounds in compost compared to digestates (Ebertseder, 2007)] are still visible, but not significant, as the increase is more apparent in the compost amendments.

These amendment-specific differences, caused by different compositions of the OS, occur as well in the BAS: In the Ss as well as in the Ut3, SDM show a higher level of BAS compared to SCM, which reflects lower degree of humification of the OS and indicates a greater content of easily available organic compounds in the soil mixed with digestate. If we consider the effects of the digestate application on the soil properties and functions and also include the input of decomposable fatty acids as carbon source for microorganisms, we need to consider more interactions in soils concerning their hydraulic or storage functions (Kirchmann and Lundvall, 1992). Combined with a high level of ammonium-N, digestates offer higher supply of precious resources for microbial growth compared to composted OS, consequently provoking priming effects. To conclude, the differences for higher priming in SDM than in SCM are caused by less stabilized OS in digestates in combination with higher amounts of available $\mathrm{N}$.

Besides the differences among the compositions of the amendments, it can be assumed that the influence on the BAS is strongly affected by the textural composition of soils, in accordance with the texture-specific influence on the carbon stock. The increase of BAS in the Ss exceeds the increase of BAS in the Ut3. Differences between the effects of SDM and SCM in the Ss compared to the Ut3 could be explained by the following:

Different accessibilities: Reasonable for the facilitated decomposition of OS in coarser Ss is the facilitated accessibility for microorganisms. In contrast, the higher clay content in Ut3 offers an extended specific surface area and a subsequent vast adsorption and storage capacity for 
organic molecules (van Veen and Kuikmann, 1990). The major preferred habitat for microorganisms is mesopores, shown by higher BAS in the unamended reference in the Ut3 compared to the Ss. From this point of view, a change of pore size distribution (shift from coarser to finer pores) in the $S$ s as a result of compost application would additionally be conceivable, as also observed in light soils by Hartmann (2002). The physical accessibility of fine pores $(<2 \mu \mathrm{m})$ is, however, impeded in fine-textured soils, because they are impenetrable for bacteria. Therefore, the protection of OS against decomposition processes increases with rising clay content.

Different $p H$ conditions: The higher BAS in the Ut3 reference compared to the Ss reference indicates improved living conditions because of its alkaline $\mathrm{pH}$ value.

Different interactions with hydrophobic substances: The significant decline of BAS of C30 in the Ut3 compared to $\mathrm{R}$ could be explained by hydrophobic humic acids, which protect the soil-inherent OS from microbial decomposition (Spaccini et al., 2002). Thus, the OS supplied with the compost may not only directly participate in humus production, but also protect the existing soil carbon pool indirectly, resulting in equal or slightly increasing $\mathrm{C}_{\text {org }}$ contents in the Ut3. Decreased mineralization as a result of incorporated hydrophobic compounds after compost application is unforeseeable in the Ss. It can therefore be assumed that texture-dependent differences in the relationship between the BAS and the RI exist, because positive correlations between reduced wettability and increasing microbial activity can be detected in the Ss, but not in Ut3. This positive correlation is also described by Feeney et al. (2006) and Annabi et al. (2007). The enhanced microbial activity may result in an increased production of exudates and mucilage which may provoke hydrophobic conditions in the Ss. The increment of microbial biomass may lead to a release of amphiphilic cell wall components during the decay of the OS (Achtenhagen et al., 2015), which could be described as a secondary process.

These findings were not reflected in the results for the Ut3, because no positive correlations could be found between the increasing hydrophobicity with decreasing microbial activity, but a decreasing BAS with rising RI. This relation was confirmed in a silty clay soil by Goebel et al. (2005). It can therefore be underlined that the supplied OS is more protected against microbial degradation in fine pore system of clay and silt fraction of Ut3 compared to Ss. But this may also have negative effects such as an increased soil hydrophobicity because of the added composted OS.
More pronounced hydrophobic conditions in the pore spaces can also cause a reduction in microbial activity by a deteriorated water and nutrient delivery (Goebel et al., 2005) and may be proofed by the decrease of BAS in the Ut3 in the SCM compared to R. Thus, not only is the new OS of the amendment less degradable in the Ut3, but also a protection of the soil-inherent OS against microbial decay occurred through adsorption in clay particles or the incorporation of organic compounds into hydrophobic components. Spaccini et al. (2002) showed that a humic acid of compost increases the carbon sequestration through reduced mineralization. Therefore, protection of OS by humic acids against decomposting can be expected only in fine-textured (silty and clay) and not in coarse-textured soils. This trend is also reflected by the results of the conducted laboratory study: the mineralization (BAS) declined in SCM in the Ut3, but not in the Ss. In a 4-year field experiment, Adani et al. (2007) could confirm a shift of carbon fraction after compost application on silty clay towards a higher proportion of humified carbon compounds compared to non-humic compounds. Using the different relations of RI and BAS in the Ss and Ut3, it can be stated that in both soils the wettability is reduced by digestate and compost. This decline is not statistically significant, but can be regarded as a trend. Already in the study of Voelkner et al. (2014), a significant reduction of the wettability in both loamy and sandy soils after addition of different fermentation residues could be observed. The lowered RI in both soils could be evoked by varying dominant mechanisms: The supply of the amendment to the Ut3 leads directly to the reduction of wettability, whereas soil wetting declines indirectly in the Ss because of increased microbial activity. When considering the RI, however, it must be kept in mind that the measurement of this value only reflects a very shortterm effect. An association between either rising BAS (in the Ss) or declining BAS (in the Ut3) and increasing RI is, however, only available in the amendments C30 in Ss and D40 in Ut3. Because the BAS is strongly increased after digestate amendment in the Ss, the RI is not increased more by digestates than by compost application. After the addition of digestates to the soil, further mechanisms appear to influence the RI. This would be underlined by the enhanced wettability of both soil types after application of high amount (D120) of digestate compared to the moderate quantity (D40). In a greenhouse experiment, Franco et al. (2000) showed that the fertilization of nitrogen-phosphate-potassium fertilizer results in a microbial decomposition of hydrophobic 
waxes and diminishes the wetting restriction of soils. This approach, in turn, corresponds to the highest increase in microbial activity in the amendment D120. The high rate of digestate appears to exhibit more effective fertilization effect on microbial activity compared to the comparable amount of compost applied. This can be explained by the more rapid fertilization effect of nitrogen of digestates. Finally, we also need to include the complex effects of the composition of the microbial biomass concerning the changes in the RI under digestate application. Hallett et al. (2001b) found in studies concerning the role of different microbial species for the development of hydrophobicity that a high fungal growth rate has more impact on development of water repellency than the huge growth of bacterial biomass. Soil-borne bacteria that are stimulated by nutrient input can reduce the water repellency, because their high activity competes with fungus growth and causes inhibition of this species. Walsh et al. (2012b) found the growth of bacterial populations to be more promoted by digestate application compared to the development of fungal communities. So the effect of stimulated bacterial population through digestates is similar to fungicide application which leads to a decreased RI in this study. This could be a clear evidence for the results: Fungi-bacteria ratio decreases in the soils with rising rate of digestates applied, therefore the water repellency is less pronounced.

\section{Conclusion}

The effects of compost and digestate on $\mathrm{C}_{\text {org }}$ and BAS are determined on the one hand by the structural composition of the OS and on the other hand by the soil texture. Whereas the addition of both amendments resulted in priming effects because of enhanced mineralization of OS in the Ss, the application of compost stabilized the amount of $\mathrm{C}_{\text {org }}$ and reduced the microbial activity (BAS) in the Ut3. Higher supply of easily available energy and nutrient sources of digestate OS caused higher stimulation of microorganisms compared to compost. Despite these evident results, the relevance of a possible interaction and competition between plant roots and microorganisms for present nutrients under field conditions remains unexpected. It can be assumed that especially in sandy regions such as the Geest in Schleswig-Holstein, digestate application may intensify the negative effect on carbon storage, because the establishment of intensively humus-consuming crop rotation already exists in this area. It may also be considered that the addition of OS leads to higher microbial activity in the longer term and increases overall aggregate stability and infiltration. These effects would require further investigation.

After compost and digestate amendment, soil wettability is reduced in both soils because of direct and indirect mechanisms; nevertheless, the hydrophobic area was not achieved. In this context, it would be necessary to investigate the effect of these organic amendments in relation to climatic factors, for example, drying and remoistening.

\section{Acknowledgements}

The authors thank the FNR (Fachagentur für nachwachsende Rohstoffe) for the financial support to this work.

\section{Annotation}

A previous version of this work was submitted previously to the journal SOIL but it was not accepted for further review. Anyhow, it was not removed from the journal's homepage and is still there online in a not-citable version.

\section{References}

Abdel-Rahman, G. (2009): Impact of compost on soil properties and crop productivity in the Sahel North Burkina Faso. American-Eurasian Journal of Agricultural and Environmental Science, 6, 220-226.

Ad-Hoc-AG, Boden (2005): Bodenkundliche Kartieranleitung. 5. Aufl., Bundesanstalt für Geowissenschaften und Rohstoffe und den Geologischen Landesämtern in der Bundesrepublik Deutschland, Hannover.

Achtenhagen, J., Goebel, M.-O., Miltner, A., Woche, S.K. and M. Kästner (2015): Bacterial impact on the wetting properties of soil minerals. Biogeochemistry 122, 269-280.

Adani, F., Genevini, P., Ricca, G., Tambone, F. and E. Montoneri (2007): Modification of soil humic matter after 4 years of compost application. Waste Management 27, 319-324.

Alburquerque, J.A., de la Fuente, C. and M.P. Bernal (2012a): Chemical properties of anaerobic digestates affecting $\mathrm{C}$ and $\mathrm{N}$ dynamics in amended soils. Agriculture, Ecosystems and Environment 160, 15-22. 
Annabi, M., Houot, S., Francou, C., Poitrenaud, M. and Y. Le Bissonnais (2007): Soil aggregates stability improvement with urban composts of different maturities. Soil Science Society of America Journal 71, 413-423.

Bayer, J.V. and G.E. Schaumann (2007): Development of soil water repellency in the course of isothermal drying and upon $\mathrm{pH}$ changes in two urban soils. Hydrological Processes 21, 2266-2275.

Blume, H.-P., Stahr, K. and P. Leinweber (2011): Bodenkundliches Praktikum: Eine Einführung in pedologisches Arbeiten für Ökologen, Land- und Forstwirte, Geo- und Umweltwissenschaftler. 3. Aufl., Spektrum Akademischer Verlag, Heidelberg.

Bustamante, M.A., Alburquerque, J.A., Restrepo, A.P., de la Fuente, C., Paredes, C., Moral, R. and M.P. Bernal (2012): Co-composting of the solid fraction of anaerobic digestates, to obtain added-value materials for use in agriculture. Biomass \& Bioenergy 43, 26-34.

Chenu, C., Le Bissonnais, Y. and D. Arrouays (2000): Organic matter influence on clay wettability and soil aggregate stability. Soil Science Societyof America Journal 64, 1479-1486.

Ebertseder, T. (2007): Humusbildung und Nährstoffbetrachtungen von Bioabfallkompost und Gärrückständen im Vergleich. In: Wiemer, K. and M. Kern (Eds.): Weiterentwicklung der biologischen Abfallbehandlung vor dem Hintergrund von TA Luft und EEG. Tagungsband, Witzenhausen-Institut für Abfall, Umwelt und Energie, Witzenhausen, pp. 219-234.

Fabrizio, A., Tambone, F.P. and Genevini (2009): Effect of compost application rate on carbon degradation and retention in soils. Waste Management 29, 174-179.

Feeney, D.S., Hallet, P.D., Rodger, S., Bengough, A.G., White, N.A. and I.M. Young (2006): Impact of fungal and bacterial biocides on microbial induces water repellency in arable soil. Geoderma 135, 72-80.

García-Bernet, D., Loisel, D., Guizard, G., Buffiére, P., Steyer, J.P. and R. Escudié (2011): Rapid measurement of the yield stress of anaerobically-digested solid waste using slump tests. Waste Management 31, 631-635.

Goebel, M.-O., Bachmann, J., Woche, S.K. and W.R. Fischer (2005): Soil wettability, aggregate stability, and the decomposition of soil organic matter. Geoderma 128, 80-93.

Hallett, P.D. and I.M. Young (1999): Changes to water repellency of soil aggregates caused by substrate-induced microbial activity. European Journal of Soil Science 50, 35-40.
Hallett, P.D., Ritz, K. and R.E. Wheatley (2001b): Microbial derived water repellency in golf course soil. International Turfgrass Society 9, 518-524.

Hartmann, R. (2002): Studien zur standortgerechten Kompostanwendung auf drei pedologisch unterschiedlichen, landwirtschaftlich genutzten Flächen der Wildeshauser Geest, Niedersachsen. Dissertation. University of Bremen.

Holm-Nielsen, J.B., Al Seadi, T. and P. Oleskowicz-Popiel (2009): The future of anaerobic digestion and biogas utilization. Bioresource Technology 100, 5478-5484.

Hurisso, T.T., Davis, J.G., Brummer, J.E., Stromberger, M.E., Mikha, M.M., Haddix, M.L., Booher, M.R. and E.A. Paul (2013): Rapid changes in microbial biomass and aggregate size distribution in response to changes in organic matter management in grass pasture. Geoderma $193,68-75$.

Kirchmann, H. and M.P. Bernal (1997): Organic waste treatment and $\mathrm{C}$ stabilization efficiency. Soil Biology and Biochemistry 29, 1747-1753.

Kirchmann, H. and A. Lundvall (1992): Relationship between $\mathrm{N}$ immobilization and volatile fatty acids in soil after application of pig and cattle slurry. Biology and Fertility of Soils 15, 161-164.

Kuzyakov, Y., Friedel, J.K. and K. Stahr (2000): Review of mechanisms and quantification of priming effects. Soil Biology and Biochemistry 32, 1485-1498.

Mataix-Solera, J. and S.H. Doerr (2004): Hydrophobicity and aggregate stability in calcareous topsoils from fire affected pine forests in southeastern Spain. Geoderma $118,77-88$.

Mshandete, A., Björnsson, L., Kivaisi, A.K., Rubindamayugi, M.S.T. and B. Mattiasson (2006): Effect of particle size on biogas yield from sisal fibre waste. Renewable Energy 31, 2385-2392.

Maylavarapu, R.S. and G.M. Zinati (2009): Improvement of soil properties using compost for optimum parsley production in sandy soil. ScientiaHorticulturae 120, 426-430.

Odlare, M., Pell, M. and K. Svensson (2008): Changes in soil chemical and microbiological properties during 4 years of application of various organic residues. Waste Management 28, 1246-1253.

Odlare, M., Arthurson, V., Pell, M., Svensson, K., Nehrenheim, E. and J. Abubaker (2011): Land application of organic waste - Effects on the soil ecosystem. Applied Energy 88, 2210-2218. 
Pell, M., Stenström, J. and U. Granhall (2006): Soil respiration. In: Microbiological methods for assessing soil quality. CABI Publishing, Wallingford, pp. 117-126.

Quédraogo, E., Mando, A. and N.P. Zombré (2001): Use of compost to improve soil properties and crop productivity under low input agricultural system in West Africa. Agriculture, Ecosystems and Environment 84, 259-266.

Ros, M., Pascual, J.A., Garcia, C., Hernandez, M.T. and H. Insam (2006): Hydrolase activities, microbial biomass and bacterial community in a soil after long-term amendment with different composts. Soil Biology and Biochemistry, 38 3443-3452.

Rowell, D.M., Prescott, C.E. and C.M. Preston (2001): Decomposition and nitrogen mineralization from biosolids and other organic materials: Relationship with initial chemistry. Journal of Environmental Quality 30, 1401-1410.

Schlichting, E., Blume, H.-P. and K. Stahr (1995): Bodenkundliches Praktikum: Eine Einführung in pedologisches Arbeiten für Ökologen, insbesondere Land- und Forstwirte und Geowissenschaftler. $2^{\text {nd }}$ ed., BlackwellWissenschafts-Verlag, Berlin, Wien.

Spaccini, R., Piccolo, A., Conte, P., Haberhauer, G. and M.H. Gerzabek (2002): Increased soil organic carbon sequestration through hydrophobic protection by humic substances. Soil Biology and Biochemistry 34, 1839-1851.

Tambone, F., Scaglia, B., D’Imporzano G., Schievano, A., Orzi, V., Salati, S. and F. Adani (2010): Assessing amendment and fertilizing properties of digestates from anaerobic digestion through a comparative study with digested sludge and compost. Chemosphere 81, 577583.

Tejada, M., Garcia, C., Gonzalez, J.L. and M.T. Hernandez (2006): Use of organic amendment as a strategy for saline soil remediation: Influence on the physical, chemical and biological properties of soil. Soil Biology and Biochemistry 38, 1413-1421.

Tillman, R., Scotter, D., Wallis, M. and B. Clothier (1989): Water repellency and its measurement by using intrinsic sorptivity. Soil Research 27, 637-644.

Van Veen, J.A. and P.K. Kuikmann (1990): Soil structural aspects of decomposition of organic matter by microorganisms. Biogeochemistry11, 213-233.

Voelkner, A., Ellerbrock, R.H., Holthusen, D. and R. Horn (2014): Wirkung von Biogasgärresten auf Benetzungseigenschaften eines sandigen Podsols und einer lehmigen Braunerde. Die Bodenkultur 65, 39-52.

Walsh, J.J., Rousk, J., Edwards-Jones, G., Jones, D.L. and A.P. Williams (2012b): Fungal and bacterial growth following the application of slurry and anaerobic digestate of livestock manure to temperate pasture soils. Biology and Fertility of Soils 48, 889-897.

Wendland, M. and K. Fischer (2013): Bei Mais die Düngung richtig berechnen. Landwirtschaftliches Wochenblatt 15, Freisingen.

Woche, S.K., Goebel, M.-O., Kirkham, M.B., Horton, R., Van der Ploeg, R.R. and J. Bachmann (2005): Contact angle of soils as affected by depth, texture, and land management. European Journal of Soil Science 56, 239-251. 